\title{
The study of knowledge employee voice among the knowledge-based companies: the case of an emerging economy
}

\author{
Elahe Hosseini, Saeid Saeida Ardekani and Mehdi Sabokro \\ Faculty of Economics, Management and Accounting, Yazd University, \\ Yazd, Islamic Republic of Iran, and$$
\text { Aidin Salamzadeh }
$$ \\ Faculty of Management, University of Tehran, Tehran, Islamic Republic of Iran
}

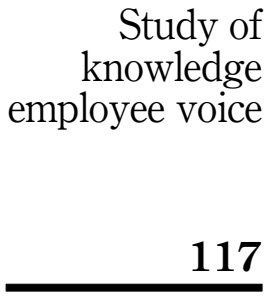

Received 11 March 2021 Revised 11 August 2021 Accepted 19 September 2021

\begin{abstract}
Purpose - A review of previous studies on the voices of employees and knowledge workers clarifies that paying attention to employees' voice is critical in human resource management. However, limited studies have been conducted on it, and much less emphasis has been placed compared to other human resource management activities such as human resource planning. Therefore, the voice of knowledge employees has been one of the critical issues that have attracted a great deal of attention recently. Nonetheless, there is no evidence of various comprehensive and integrated voice mechanisms. As a result, this study aims to design knowledge workers' voice patterns in knowledge-based companies specialising in information and communication technology (ICT) in Iran in May and June 2020.

Design/methodology/approach - This study is a qualitative grounded theory research. We collected the data from a target sample of 15 experts in knowledge-based ICT companies using in-depth semi-structured interviews. Since all the participants had practised the employee voice process, they were regarded as useful data sources. Data analysis was also performed using three-step coding (open, axial and selective) by Atlas T8, which eventually led to identifying 14 components and 38 selected codes. We placed identified components in a paradigm model, including Personality Characteristics, Job Factors, Economic Factors, Cultural Factors, Organisational Policies, Organisational Structure, Climate Of Voice in the Organisation, Management Factors, Emotional Events, Communications and Networking, Contrast and Conflict and, etc. Then, the voice pattern of the knowledge staff was drawn.

Findings - The results showed that constructive knowledge voice influences the recognition of environmental opportunities and, additionally, it helps the competitive advantages among the employees. By forming the concept of knowledge staff voice, it can be concluded that paying attention to knowledge staff voice leads to presenting creative solutions to do affairs in critical situations. The presentation of these solutions by knowledge workers results in the acceptance of environmental changes, recognition and exploitation of new chances and ideas, and sharing experiences in Iranian knowledge-based companies.

Practical implications - Strengthening and expanding the voice of employees in knowledge-oriented companies can pave the way to growth and development towards a higher future that prevents the waste of tangible and intangible assets.
\end{abstract}

(C) Elahe Hosseini, Saeid Saeida Ardekani, Mehdi Sabokro and Aidin Salamzadeh. Published in Revista de Gestão. Published by Emerald Publishing Limited. This article is published under the Creative Commons Attribution (CC BY 4.0) licence. Anyone may reproduce, distribute, translate and create derivative works of this article (for both commercial and non-commercial purposes), subject to full attribution to the original publication and authors. The full terms of this licence may be seen at http:// creativecommons.org/licences/by/4.0/legalcode

The authors would like to thank all researchers who helped in this research, especially the researchers in the Faculty of Economics, Management and Accounting of Yazd University and employees of knowledge-based companies in Iran.

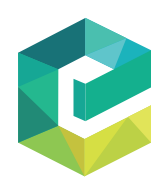

Revista de Gestão Vol. 29 No. 2, 2022 pp. $117-138$ Emerald Publishing Limited e-ISSN: $2177-8736$ p-ISSN: $1809-2276$ DOI 10.1108/REGE-03-2021-0037 
REGE

29,2
Originality/value - Companies' ability to engage in knowledge workers is a vital factor in human resource management and strategic management. However, the employee voice has not been involved integrally in the context of corporate.

Keywords Organisational voice, Knowledge employee, Employee voice, Knowledge employee voice, Knowledge-based companies

Paper type Research paper

\section{8}

\section{Introduction}

Nowadays, organisations must move in a turbulent environment, with uncertainty and unpredictability resulting from technological, social, political and economic changes (Salamzadeh, Tajpour, \& Hosseini, 2019). That is why in today's evolving world, the foundations of industrial economies have shifted from the focus on resources to the focus on intellectual capital (Tajpour, Hosseini, \& Alizadeh, 2021). In such situation, society needs new companies based on knowledge, basically called knowledge-based companies.

Knowledge-based companies, as knowledge-centred companies, attempt to be learning organisations where members strive to improve their knowledge production capacity as a group and individually (Salamzadeh, Tajpour, Hosseini, \& Salembrahmi, 2021). Knowledge must be created and exchanged in different forms to create value for activating growth and development in knowledge-based companies (Bouncken, Kraus, \& Roig-Tierno, 2019). As a result, knowledge-based companies are those that sell their knowledge (Sveiby, 1997). The growing number of knowledge-based companies has led to creating many novelty products and preparing the ground for investors and elites to be involved in the business (Salamzadeh \& Kawamorita Kesim, 2017).

Knowledge-based companies' management is confronted with complexities in developing countries like Iran, such as the lack of trust among employees, little creativity and knowledge sharing, improper hierarchical and governmental structure, lack of a proper business model, lack of material and spiritual incentives to foster innovation, lack of enthusiasm for innovation, inadequate technical skills of employees, low level of hardware and software technology, and insufficient support by the government (Madhoshi \& Kia Kojouri, 2018).

Similar to other companies, knowledge-based companies have financial, commercial concerns and aim to create wealth. However, these companies attempt to generate wealth through scientific research development and the upgrading of sophisticated and efficient technologies, which is known as the main difference between their goal and other commercial companies' (NawzadSabir, Othman, Al-Kake, \& Rashid, 2019). Compared to mature firms, knowledge-based firms have the potential to grow more, expressing that they can have more workforce or the opportunity to grow with less capital than older companies (Epstein \& Yuthas, 2017).

In this regard, it can be said that knowledge-based companies are looking for the best way to operate and strengthen relationships based on collaboration to achieve organisational perfection by searching for a superior position in the market (Wang \& Ahmed, 2003). Therefore, due to the change in the concept and structure of knowledge, knowledge has become necessary in economics, as well as the whole knowledge society, and knowledge employees (Adelstein, 2007).

Then, successful organisations, especially knowledge-based companies, seek to use human capital as a competitive advantage, and discover innovation as a critical factor in achieving success (Kantur, 2016). In other words, according to resource-based theory, it might be difficult for organisations to access such resources and capabilities. However, since they cannot be imitated by other organisations, those resources play a significant role in the competitive advantage of organisations (Reed \& DeFillippi, 1990). Consequently, knowledge workers were recognised as a great source of innovation and competitiveness (Chen, 2008). 
Knowledge employees create new ideas, are engaged in knowledge dissemination and use knowledge as a resource. They also participate in research and development and are industriously involved in the advancement of knowledge (Ötken \& Cenkci, 2012).

Knowledge employees are responsible for their working lives. They are continually striving to better understand the world and improve their work practices and behaviours to achieve organisational and personal goals. They also have a self-motivating force (Greene, 2006). These unique features allow knowledge workers to find and solve problems. So, knowledge-based companies need the feedback of their knowledge employee in order to make successful organisational changes (Holland, Teicher, \& Donaghey, 2019). Therefore, the opportunity to know employees through their opinions can play a significant role in organisational performance, innovation, security, and operational development process (Coule, 2013). Besides, the information provided to decision-makers promptly enhances the quality and accuracy of decisions (Kok, Sarikaya, \& Coban, 2016).

According to the expectancy theory of motivation, if managers impose conditions on employees to make their voices heard, employees will realise that they are valued by management. It motivates them, which ultimately leads to high organisational productivity (Green \& Tsitsianis, 2005). Therefore, mutual trust between employees and managers can create an atmosphere full of employee participation (Charkhkar, Hosseini, \& Sabokro, 2021). As a result, it can help increase their motivation, provide creative suggestions and create the appropriate platforms and infrastructure for knowledge employees to achieve organisational goals, which are essential (Norman, Avey, Larson, \& Hughes, 2019).

Knowledge-based companies face a great number of changes and challenges that oblige them to employ elite and talented people, thus diminishing the impact of these challenges, especially in occupations and positions crucial to move towards decision-making (Salamzadeh \& Tajpour, 2021). Evidently, the closer the source of decision-making is to the problem, the more practical the solution is (Tajpour \& Hosseini, 2021b). Indeed, knowledge-based companies can provide people with the opportunity to express their ideas or voices. And it will enable talented people to assist in understanding the organisation's problems and seek creative and new ideas to solve their problems. Nonetheless, the motivation for such behaviours cannot be found only in the context of organisational systems. Unfortunately, previous studies have not yet addressed this issue.

Therefore, the paper sought to provide a model for knowledge employee voice in Iran. The findings of this study can significantly help managers and owners of knowledge-based information technology companies to achieve competitive advantage. In summary, this study contributes to the mainstream literature in four ways: First, it extends the employee voice literature and relates it to knowledge-based companies that are innovative in their own right. Second, it extends the employee voice literature to address the call for reconsidering the structures, processes and context change. It also covers the need for relating employee voice to some concepts, including organisation and management. Third, it contributes to a competitive advantage in the organisation through examining the impact of employee voice. Fourth, this study addresses the need for more empirical studies on the effectiveness of employee voice in developing countries such as Iran. In the continuation of this research, theoretical foundations and background on employee voice and knowledge worker are assessed. Then, the research method is expressed. Later, the pillars of the employee voice model of knowledge are extracted by presenting the voice components of the knowledge employee. In the end, a grounded theory of knowledge employee voice is presented based on the paradigm model, and the results and suggestions of the research are also stated.

\section{Employee voice}

The quick environmental changes are among the most critical challenges for organisations, as well as the extended and increasingly competitive environment, which permanently makes 
REGE 29,2

organisations strive for success (Hosseini, Saeida Ardekani, \& Sabokro, 2021b). Therefore, the interaction based on trust - that is, between manager and employees - is required (Gao, Janssen, \& Shi, 2011). Indeed, the employees' ideas of working hard to keep their position in a competitive environment are crucial for an organisation (Kok et al., 2016). Accordingly, employees are provided with opportunity for expressing their ideas using the concept of voice; however, it seems that they are now willing to do so in any circumstances. Hence, it is necessary to encourage them to voice their ideas.

Therefore, knowledge-based companies invest in programmes that can increase the participation of knowledge employees (Khanmoradi, Sajjadi, \& Zardoshtian, 2020), since not all employees are known as a source of competitive benefit for the company (Kryscynski, Coff, \& Campbell, 2021). Welbourne (2011) also asserts that when employees express activity knowledge and are not like robots doing just a simple, repetitive task, then it is clear that companies are growing and developing (Welbourne, 2011). The best term for voice goes back to the classics of Hirschman (1970), who observed voice as an attempt to change, rather than escape from a troublesome situation (Hirschman, 1970). Employee voice has been a longstanding research topic developed by Freeman and Medoff(1984), that traces its origins to more than two centuries ago and has only been known to be conservative in trade unions (Kaufman, 2015). Enthusiasm for studying employee voice has been increasing exponentially in recent years, and scientists have identified among the various disciplines the factors associated with employees involved in employee voice and its consequences for organisations (Mowbray, Wilkinson, \& Tse, 2015). Employee voice is essential because it is a strong incentive for highquality decisions and organisational success (Morrison, Wheeler-Smith, \& Kamdar, 2011). Moreover, employee voice is beneficial for the early detection of serious problems (Detert \& Burris, 2007). Therefore, the new forms of employee voice in organisations appeared quickly, including self-governing teams, proposals and open-door policies, which were more participatory (Wilkinson, Dundon, Donaghey, \& Freeman, 2014).

The voice is known as a discretionary or formal expression of comments, ideas, suggestions and approaches about an organisation, group, personal changes, or improvements (Bashshur \& Oc, 2015). Sometimes, the voice is considered an elective speech for discussing effective functioning in professional fields (Liang, Farh, \& Farh, 2012). Voice behaviour emphasises effective statements rather than criticism (Hu et al., 2018).

The organisational voice is a constructive behaviour, and it is not a factor of dispute between employees to develop the organisation's structure (Van Dyne \& LePine, 1998). The organisational voice usually includes internal and external managerial authority. Moreover, organisational authority is different from organisational opposition. The organisational opposition includes reports about misbehaviour at special units; conversely, the organisational voice talks about practical ideas for improving the current job process (Boxall, Freeman, \& Haynes, 2018). The complaint is that the other concept tells about dissatisfaction, and does not necessarily make any practical suggestions, so it should be separated from the field of organisational voice (Holland et al., 2019).

The employee voice is defined as follows: how employees' anxiety is increased and how they follow the best way for solving their problems, participating and cooperating in professional decision makings (Pyman, Cooper, Teicher, \& Holland, 2006). Morrison et al. (2011) tell us about the existing limitation, which requires more focus on the type of message and transforming data. Recently, Burris (2012) reminded us of the improvement-oriented voice meaning by determining two kinds of challenging voice to correct existing situations: speech and threaten factors (Burris, 2012). Recently, Maynes and Podsakoff (2014) have collected vast samples of employee voices and valid indicators of voices to expand it to four types of voices. It is the same as the supportive voice of Burris (2012). There are two challenges related to the voice, as follows: First, a suggestive voice is designed to improve the situation and is known as a speech. The second is a supportive voice, known as improving, 
designed to stabilise techniques, poultices, and it talks about threats of the current situation. Besides, Maynes and Podsakoff (2014) have developed a vast collection of patterns and indicators for four types of voices. The supportive voice is the same as Burris's supportive voice (2012). The constructive voice is the same as the community friend voice of Van Dyne and LePine (1998). The defensive voice is opposed to job policy changes and so on. Even when some changes are required and the policies are criticised, the voice completely disagrees (Maynes \& Podsakoff, 2014). They suggest a reviewed expression about employee voice as a liberal, voluntary information, with the suggestion of checking employees' affection for the job-environment (Mowbray et al., 2015). On the other hand, there is no precise mechanism for voices, as it points to ideas and challenges outside the organisational structures and happens in personal interactions between management and employees (Mowbray et al., 2015).

Human management studies consider that the goal of voice is management. Trust in managers is an essential factor for voice opportunity creation (Bang, 2012). The managers are a distinctive group affecting the employee voice and its consequences. At first, for the appearance of the voice, employees check the propitiousness of the situation (Is it propitious to talk or not?). The first factor is the interaction with management, so interacting with management is crucial in employee risk-taking for voice (Huang \& Paterson, 2017). However, there are other groups of people who are influential as much as managers. The line managers are a productive group and act like managers. They can provide a situation to destroy the voice, use the voice, or avoid it altogether (Townsend, 2014).

Pohler and Luchak (2014) point to some factors that can fill the gap between employee voice and necessary attention (Pohler \& Luchak, 2014). These factors create a unique factor that encourages the employees' voice (Islam, Ahmed, \& Ali, 2019). Employees show their dissatisfaction in two ways. First, they leave the company. Second, they share their ideas and views about improving the situation (Crant, Kim \& Wang, 2011). Grant (2013) believes that the employees demonstrate their voice in a constructive manner, using effective strategies to modify emotions. The employee voice literature of human resources management believes that senior management usually chooses challenging choices for employee voice, but leaders and managers accomplish the design system. As a result, this situation provides an opportunity for researchers to help one another and develop literature (Hosseini \& Sabokro, 2021).

The knowledge employees are the economic participation in creating and distributing intangible sources (Tajpour, Salamzadeh, \& Hosseini, 2019). So, they have to be experts and have a high-tech education. They are trying hard to achieve better cognition about the world and correct their actions in order to have a better performance, self-motivate, they do not care about money, they cannot be bribed, they do not need money or technology for performance and they feel responsible for improving their work (Greene, 2006). This unique feature helps knowledge employees to follow a problem-solving attitude in their profession (Nicolopoulou, Karatas-Ozkan, \& Tatli, 2007). Education is the other feature of knowledge employees (Tajpour, 2021). Draker believes that education and qualification are inseparable and require factors for official and unofficial fields. Knowledge workers help change the educational systems and encourage the educational experts for professional education required by employees and companies (Stromquist et al., 2007). If the organisation clarifies the important field, the knowledge will turn from production into process (Tajpour \& Hosseini, 2021a). It becomes the duty of knowledge employees to find the activation process (Massey, MontoyaWeiss, \& O'Driscoll, 2005). The progress will show the effect of the intended job (Liu \& Wu, 2008). Respectful employees have more opportunities to have a better position in the future and show the voice mechanisms (Chen, Wang, \& Lee, 2018). When employees have a strong perception about their job, their internal desires are more important than external ones (Chamberlin, Newton, \& Lepine, 2017). If the manager wants to listen to employee's voice, they must speak and participate in decision-making situations (Holley, Wu, \& Avey, 2019). Strauss (2006) believes that the concept of voice, in terms of voice effect, is weaker than other 
REGE 29,2

concepts such as cooperation. The voice does not show the collaborative power or influence, but it shows the influence on company management, even when the employees do not achieve the expected results. Then, Strauss (2006) refers to the employee voice as a win-win solution for most company problems, and finds a solution for solving the employee's problems.

Tangirala, Kamdar, Venkataramani and Parke (2013) concluded that employees with higher responsibility might use more voice power, and accept it as a role. The voice is a kind of ultra-duty behaviour chosen consciously and intensely to express influential views to improve the situation (Mowbray, Wilkinson, \& Tse, 2019). Researchers postulate a positive relationship between voice behaviour and employees' effectiveness, such as progressive results of a person or organisation (Hyman, 2018).

\section{Research methodology}

The aim of this research is practical, and the qualitative method has been applied for data collection: it has been used in the field of organisational behaviour and human resources. Accordingly, it tries to answer this question: what is the pattern of the knowledge employee voice in knowledge-based companies in the field of information technology in Iran? Grounded theory has been used to acquire ample qualitative data to construe and explain the target phenomenon's subjective connotation. In this type of research plan, more importance is given to qualitative data, in order to gain a real insight regarding the issues and the nature of the topic (Cresswell, 1998). This may refer to authentic experiences pertinent to the issues under examination, particularly helpful while describing hidden and unanticipated subjects (Sabokro, Kayedian, \& Hosseini, 2021). It can also be influential for specific researches (Palalic, 2017). Besides, we have decided to apply this method because the core objective is to choose the individuals acquainted with such phenomena. As a result, the present research will be consistent with the interpretive research paradigm. In other words, it can lead to the development of the perception of the social phenomenon and the investigation of its meaning in a particular context, where the people's perspectives and experiences are regarded as the primary source of insight (Kamarudin, Starr, Abdullah, \& Husain, 2014). According to Wei, Kang, Zhang and Zhang (2016), describing the basis of the phenomenon and establishing the ground for clarification are considered the grounded theory's goals. In this regard, in the same vein, this theory can be used for rendering an in-depth standpoint to reveal the assets of the phenomena (Zahra, 2007), which refers to the inherent essence of the knowledge employee voice. Consequently, it will be easier to comprehend the topic so that the samples can provide appropriate answers accordingly (Hosseini, Saeida Ardekani, \& Sabokro, 2021a). It is also recommended because of the objective of the study and the internal judgement: unlike quantitative studies, qualitative research is less likely to provide arranged procedures, particularly in terms of sampling (Palalic, 2017).

\section{Participants}

In accordance to Strauss and Corbin's (1990) approach, the researchers favoured the relatively homogeneous samples in knowledge-oriented companies to consider the worldwide perspective toward the context of the knowledge employee voice and highlight this study's context. The study population includes knowledge-based companies that are defined and categorised, based on the evaluation regulations of Iranian knowledge-based companies and institutions. They are private companies or institutions that have been created to expand and apply inventions and innovations, as well as to commercialise the results of research and development (including the design and production of goods and services) in the field of high technology. In Iran, knowledge-based companies fall into three general categories, including companies producing knowledge-based products, companies providing knowledge-based services and start-up knowledge-based companies. This research has focused on companies 
providing knowledge-based services, i.e. companies providing specialised and consulting services, producing new products or technology and conducting applied research.

The researchers chose this type of knowledge-based company because if a manufacturing company produces a defective product, it may be discovered during the production process; it is therefore likely to be modified or abolished before it reaches the customers and disappoints them. However, an incomplete or substandard service will quickly become apparent to the customer in the majority of knowledge-based service companies. This is critical to the success of knowledge-based service companies. Managers of knowledge-based service companies must ensure that customers will experience a high level of quality standard to strive to compete among manufacturing and service knowledge-based companies. Given the multitude of relationships with other workgroups and customers, they are more exposed to the voice. Then, managers' attention to the voice of knowledge employees can help them achieve a competitive advantage and create innovative solutions. In this study, selected companies should have more than five years of existence and should have gone through failure and revival. Highlighting knowledge employees' voice can lead companies from failure toward revival.

Knowledge-based companies with different functions were considered, because multiple samples enhance the stability and consistency of the results and improve the validity of the study. Moreover, the selection of target samples follows the positivist approach, improves the generalisation of results and allows the researcher to use various sources and combine several research strategies and different data (Fakhari, 2021).

Then, the participants were selected among them. Fifteen individuals (including managing directors, board members, marketing and sales, product development, executives and the internal manager of knowledge-oriented companies) in the field of information technology were selected through the implementation of a theoretical approach. All the participants had already practised the employee voice procedure in their ranks; thus, they were regarded as useful information sources. Table 1 indicates the participants' organisation information as follows:

\section{Data collection}

Creswell (2002) believed that rich data are considered the building blocks of grounded theory studies (Creswell, 2002). Accordingly, one can get meaning and concept by using available information, and there is no variable. In this research, we have used semi-structured

\begin{tabular}{lllr}
\hline $\begin{array}{l}\text { Interviewees } \\
\text { code }\end{array}$ & Case & Organisational position & Experience (years) \\
\hline A1 & Providing specialised and consulting & Board member & 41 \\
A2 & services & Strategic manager & 33 \\
A3 & & Engineering services & 13 \\
A4 & & Internal manager & 8 \\
A5 & Subscriber affairs & 5 \\
A6 & Production of new products or & Product development & 11 \\
& technology & manager & 9 \\
A7 & & Engineering services & 17 \\
A8 & & Expert & 14 \\
A9 & & Executive expert & 27 \\
A10 & Subscriber affairs & 17 \\
A11 & Conducting applied research & Engineering services & 23 \\
A12 & & Public relations & 14 \\
A13 & Internal manager & 15 \\
A14 & Supervisor & 24 \\
A15 & & & 9 \\
\hline
\end{tabular}

Table 1. Participants' information 
REGE

29,2

124

interviews with authorities to collect additional information to extract from knowledge employees of knowledge-oriented companies in Iran. Authorities of knowledge-based companies in Iran were the favoured society for this research. People who received and answered to ideas and recommendations were criteria for choosing members. In this method, one can reach meaning and concept through available information, and there is no variable. For this purpose, in-person interviews were prepared in September 2019. Then, the recorded and transcribed interviews were translated into English. It is worth noting that the interview with participants was longitudinal.

The interview questions focused on knowledge workers and employee voice in knowledge-based companies. The sequence of questions was not the same for all participants and depended on the interview process. There was not a pre-constructed pattern in the design of the interview questions. The researchers conducted each interview focused on obtaining qualitative data independently and in an exploratory manner, regardless of previous results, and analysing the results without any specific manipulation or mental model. In the present study, the questions were mainly formed with the following 5W1H question marks: how, what, why, when, where and who. There were seven questions in this stage; for instance, "What are the effective indicators of knowledge employee voice in knowledge-based companies in Iran?", "What are the implications of knowledge employee voice in knowledge-based companies?" and "What are the factors that facilitate knowledge employee voice in knowledge-based companies?". Each interview would be performed for 4575 minutes on average; besides, axial and open coding approaches were used.

\section{Data analysis}

Three approaches of design, adaptation and adaptation-design are commonly applied to develop knowledge employee voice patterns. The present study used the design approach. As a result, respective model development and model assessment processes among Iranian knowledge-based companies were performed. The researchers employed the grounded theory premise, which was proposed by Strauss and Corbin (1990), for data analysis. Accordingly, the grounded theory paradigm was developed to concentrate on the research questions; it includes the following stages: open, axial and selective coding.

\section{Preparing a preliminary list of knowledge employee voice using individual interviews}

This stage refers to the implementation of interviews to determine underlying factors in knowledge employee voice. Then, these components will be extracted based on the analysis of experts' opinions and the initial list will be developed accordingly. Theoretical saturation was reached after performing 15 interviews in this study. A specialist transcribed each interview into a word processing document. After completing the transcriptions, interviewers read these transcripts and made suggestions for revisions, primarily based on their notes taken during the interviews. Also, verbal expressions were converted into a more formal format (Andrews, Tierney, \& Seers, 2020). Some examples of verbal statements or identified codes are represented in Table 2.

\section{Comparing the obtained list with the lists and the pattern of knowledge employee voice}

Open and selected coding processes were used for the analysis of qualitative data. It is also noteworthy that these two steps are interconnected and may occur simultaneously. At first, appropriate titles were assigned to primary themes, and respective categories were developed accordingly. Eventually, the principal category was extracted based on the relationships among primary categories, which could lead to a theory to illuminate the issue.

Irrespective of the potential relationships, several codes will be extracted in the open coding stage (Cresswell, 1998). A line-by-line approach was used to conduct open coding where the 
data were collected inside the study setting and analysed externally. It is also noteworthy that the data will be assessed meticulously in this approach. At this stage, the ultimate code was extracted due to integrating open codes to the researcher's notes. In the next step, i.e. axial coding, the codes were integrated based on categorisation. Then, relationships among the codes were explained using selective coding (Denzin \& Lincoln, 2008).

Ultimately, the researchers would compare primary codes to the outcomes of previous studies in order to extract new components. These components were then added to the original list of knowledge employee voices. The final list (No. 2) of the extracted codes was formed after reviewing the content and analysing the sources. All the transcripts were then stored in Atlas ti8, which supported data analysis.

It is also noteworthy that interactive and recursive processes, and a higher level of abstraction in axial and open coding, are applied to conduct the analytical measures at this stage (Strauss \& Corbin, 1990). The procedure will carry on until the significant abstract categories are entirely unified, leading to the formation of a larger scheme where the research results are regarded as a coherent theory (Strauss \& Corbin, 2008). Figure 1 indicates the relationship between different steps of data analysis and data collection procedures.

\section{Defining knowledge employee voice concepts}

This step includes researchers evaluating knowledge employee voices assigned to lists No. 1 and 2. After integrating the results of the interviews to other resources, the final draft for the
Study of knowledge employee voice

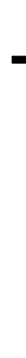

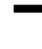


REGE 29,2

knowledge employee voices index was formed. The categorisation of extracted codes was performed using conceptual correspondence.

\section{Evaluating and refining the list of knowledge employee voice}

The narrative approach was implemented to collect the data from individual interviews. For this purpose, the Delphi method was applied for model development: at first, a Delphi panel was developed, and samples were identified after providing a comprehensive explanation of the objectives and problem of the present research. Selected experts would then receive an invitation, along with the central components and practical factors, in order to comment on the need to add to or reduce the proposed components. The second stage included the development of a questionnaire for knowledge-based companies; this instrument was designed according to the results of previous studies in the literature as well as in-depth exploratory interviews. The questionnaire was sent to the panel of experts to receive their constructive feedback. Eventually, the ultimate model of knowledge employee voice for Iranian knowledge-based companies was developed when the experts assessed the items. The interviews were halted after obtaining data saturation to categorise them into different groups. The final model contained 14 categories and 38 selected codes.

\section{Reliability and validity}

When different people agree on the validity of the test, that test has content validity. The content validity ratio (CVR) index was used in the present article to determine the content validity. To calculate this index, a questionnaire was designed based on the components extracted from Table 3 and sent to seven experts and professionals in the field of employee voice, and the objectives of the test were clarified accordingly. Operational definitions relevant to the content of the questions were provided: they were asked to categorise each question based on Likert's three-point scale including "the component is necessary", "the component is useful but not necessary" and "the component is not necessary". Then, according to Formula (1), the CVR was calculated (see Table 4).

$$
\mathrm{CVR}=\frac{\text { Number of experts who have selected the item "necessary" }-\frac{\text { Total number of experts }}{2}}{\frac{\text { total number of experts }}{2}}
$$

According to the table above, questions for which the calculated CVR value is less than the desired amount, considering the number of experts evaluating the question, should be excluded from the test, as they do not have acceptable content validity. As the number of experts in the present study is seven, according to Table 3, the items whose CVR index is below 0.99 were excluded from the questionnaire. In addition to the CVR index, that deleted some indicators according to experts, the merging and overlapping of items were also investigated during the discussion with experts while mentioning the logical reasons for removing some components. In other words, the main idea mentioned by the experts was that the number of components was too large and they were too long; moreover, there were overlaps between some components.

Table 5 indicates that the inter-coders reliability coefficient was $75 \%$. In addition, the reliability of the present research was assessed based on the experts' opinions and evaluations using the following formula:

$$
\text { C.R. }=(2 M) \%(N 1+N 2)
$$

where CR refers to the reliability, $M$ refers to the number of codes based on consensus, and $N 1$ and $N 2$ refer to the first and second decisions. 


\begin{tabular}{lll}
\hline Row & Class & Dimension \\
\hline 1 & Causal conditions & Personality characteristics
\end{tabular}

Chosen code

High self-confidence

Independence (sense of responsibility)

Risk taking ability

Job factors

2 Context

Economic factors

Cultural factors

Organisational policies

Organisational structure

$3 \quad$ Influential conditions

4 Consequence

Emotional events

Individual level

Unit level

Organisation level

$5 \quad$ Strategies

Communications and networking

Contrast and conflict
Job stress

Job attitude

Job security

Economic competition among organisations

Poor economic situation (sanctions and threats)

Cultural characteristics of employees within the organisation

The culture of accepting new ideas

The culture of getting involved at work

Working methods and procedures

Reward and punishment policies

Process formalisation and standardisation

Company strategies

Using new technologies

Encourage employees to be creative and

innovative

Pay attention to the physical space of the workplace

The extent to which employees participate in decisions

The level of management support for employees in expressing new ideas

Track management in order to do the job

Failure or success in the workplace

Unexpected events

Reduce the number of employees leaving the service

Promotion and job satisfaction of knowledge employee

Learning and strengthening work experience through knowledge sharing

Influence decisions by providing information

Eliminate internal conflicts and destructive competition

Achieving competitive advantage

Improving internal and external relations

Create the desired social image of the company

Organisational productivity

Preventing the waste of material and non-material capital of the organisation

Collective interactions

Long-term cooperation with other companies and suppliers

The quality of supervisor-subordinate

relationships

Lack of information transparency

No division of labour

\section{Study of knowledge employee voice}

127

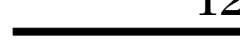


REGE

29,2

coding process until the selective coding stage. Hence, they are expected to develop a theory throughout the data collection stages.

\section{Results}

The exploration of the knowledge employee voice grounded theory was performed through the qualitative perspective of this paper's grounded theory approach. The findings consisted of the interactional strategies, the primary phenomena, the causal conditions, as well as the respective conditions and context in which the strategies and the consequences of the employee voice process were developed in the large knowledge-oriented companies in Iran. Therefore, the content, the process of different dimensions of the employees' voice and the respective propositions are explained in the following section. Besides, the coherent process model of knowledge employee voice is shown in Figure 2.

This research attempted to present a pattern for knowledge employees' voice in knowledgeoriented companies in Iran. This article made critical theoretical contributions to the knowledge of employee voice literature. Besides its theoretical contributions, this research has implications for management practice. Especially managers should be supporting employee voice. A unified conceptualisation of employee voice can contribute to establishing substantial opportunities for different disciplines to improve the employee voice literature and draw new conclusions. For this evaluation, we applied the grounded approach proposed by Strauss and Corbin (1990). Finally, we represented five main aspects of this approach, including causal conditions, background situations, strategic situations, intervention situations, results in a chart, etc.

\begin{tabular}{lccccc}
\hline Number of experts & CVR value & Number of experts & CVR value & Number of experts & Value CVR \\
\hline 5 & 0.99 & 11 & 0.59 & 25 & 0.37 \\
6 & 0.99 & 12 & 0.56 & 30 & 0.33 \\
7 & 0.99 & 13 & 0.54 & 35 & 0.31 \\
8 & 0.75 & 14 & 0.51 & 40 & 0.29 \\
9 & 0.78 & 15 & 0.49 & & \\
19 & 0.62 & 20 & 0.42 & & \\
\hline
\end{tabular}

Table 4.

Minimum acceptable CVR value based on the 8 number of evaluating professionals

\begin{tabular}{lcccc}
\hline Components & $\begin{array}{c}\text { Reliability } \\
\text { coefficient }\end{array}$ & $\begin{array}{c}\text { Weight of each } \\
\text { component }\end{array}$ & $\begin{array}{c}\text { Reliability coefficient: } \\
\text { weight of each } \\
\text { indicator }\end{array}$ & $\begin{array}{c}\text { Reliability } \\
\text { coefficient average }\end{array}$ \\
\hline $\begin{array}{l}\text { Personality } \\
\text { characteristics }\end{array}$ & 0.86 & 0.74 & 0.636 & 0.75 \\
Job factors & 0.91 & 1.23 & 1.119 & \\
$\begin{array}{l}\text { Economic factors } \\
\text { Cultural factors }\end{array}$ & 0.75 & 0.80 & 0.600 & \\
Organisational policies & 0.69 & 0.73 & 0.503 & \\
$\begin{array}{l}\text { Organisational } \\
\text { structure }\end{array}$ & 0.85 & 0.89 & 0.828 & \\
Climate of voice in the & 0.87 & 0.83 & 0.705 & \\
organisation & 0.79 & 1.16 & 0.705 & \\
Management factors & 0.90 & 0.87 & 0.916 & \\
Emotional events & 0.783 & 0.631 & \\
Communications and & 0.83 & 0.76 & 0.828 & \\
networking & 0.93 & 0.89 &
\end{tabular}

Table 5.

Reliability coefficient

Contrast and conflict 


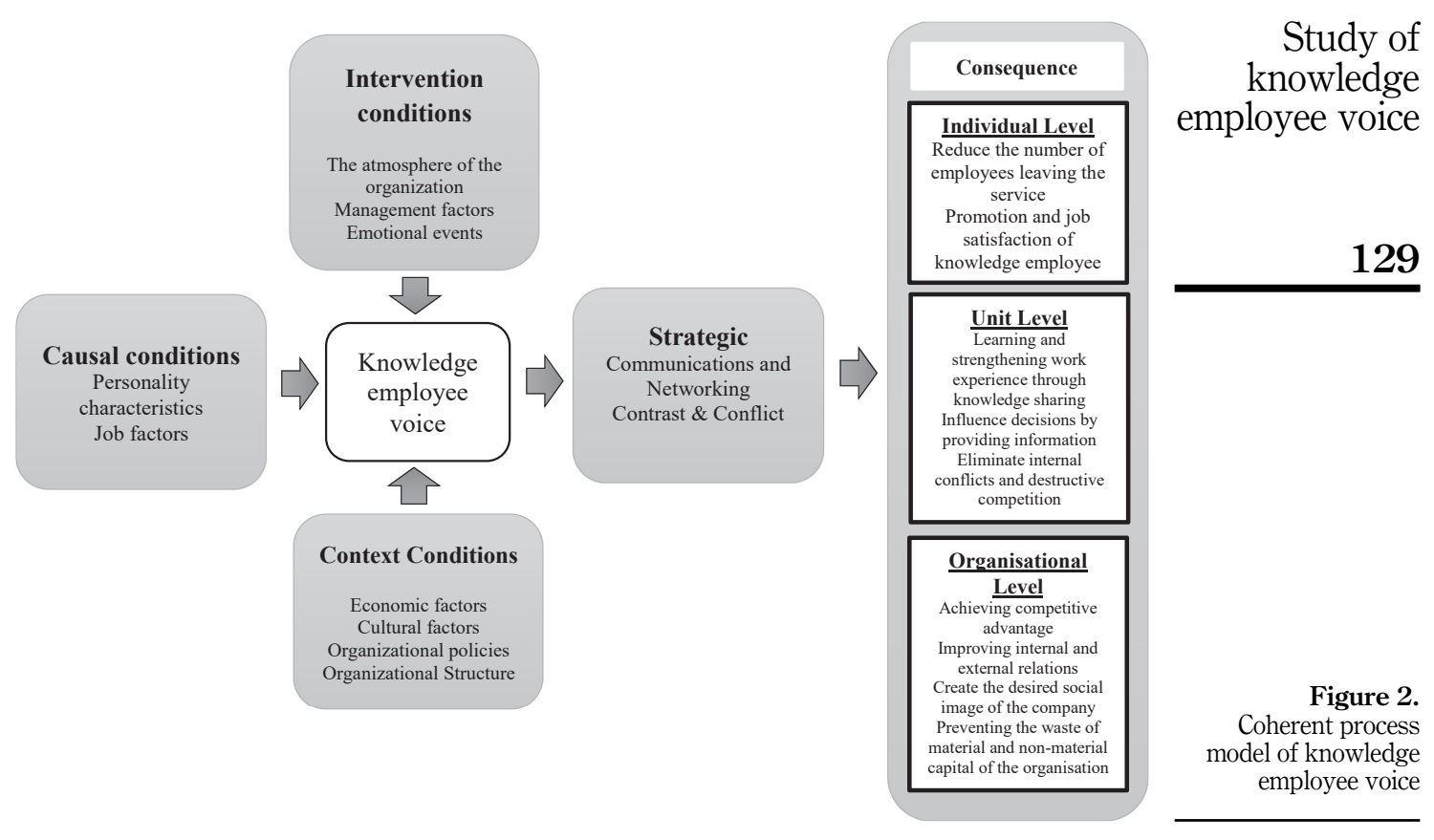

After designing the paradigm model, it can be said that the first step of the model for expressing the voice of knowledge employees was causal conditions including personality and job characteristics. This component includes happenings leading to the occurrence or growth and expansion of a phenomenon, events, incidents and circumstances that lead to the occurrence or spread of a phenomenon. Causal conditions, or what is occasionally called preferred conditions, are primarily expressed in data in terms such as "when, while and because". This stage can be called preparation or pre-implementation stage. At this stage, the organisation does not explicitly create the voice of employees, but provides conditions for its occurrence. This stage includes the factors which lead to the occurrence of knowledge employees' voice.

The next step is to create the voice of employees as a phenomenon. It is a component that always appears in the data, and other key components are related to it. The other section of the paradigm model includes the strategies to be implemented to achieve the voice of knowledge employees in the company. These include the actions that are taken to control and manage the central phenomenon and the steps extracted, and the relationships between them are here. The strategies of the basic theory include a method of theorising with interaction/ interaction bias, whether it is an individual, a group, or a collective study, whose aim is to manage, deal with and fulfil, to show sensitivity to the phenomenon. Contextual conditions in this model must exist in order to take appropriate actions and strategies. These conditions include those which affect the voice of knowledge employees.

Moreover, another factor is the intervening conditions, which include concepts that increase or decrease the occurrence of voice when strategies are being implemented. These factors, as facilitators and contributors, affect the voice of knowledge workers. Eventually, the consequences in the paradigm model indicate the results of the expression of knowledge employee in three dimensions, including individual, unit and organisation (Strauss \& Corbin, 2008). 
REGE

29,2

\section{Conclusions}

Employee voice has been extensively investigated recently. Moreover, companies' ability to engage in knowledge workers is a vital factor in human resources management and strategic management. Despite significant studies in both fields, the circumstances leading to knowledge employee voice and the respective consequences have not been completely illuminated. Researchers on management consider employee voice as the process in which a corporation apply novelty to renovate the firm and achieve competitive advantage. Nonetheless, the researchers have not investigated employee voice along with the context of the corporation. This paper aimed to explore the consistent process of employee voice, and the content and consequence of knowledge employee voice as the feature of developing a coherent theory that describes the knowledge employee voice process. Accordingly, the research has demonstrated that knowledge employee voice refers to investigating and implementing opportunities.

The present study can have empirical and theoretical contributions to the literature regarding voice. The respective empirical outcomes highlight the pattern of knowledge employee voice for knowledge-oriented companies in Iran. It should also be noted that the investigation of organisational employee voice has been relatively ignored in previous studies in Iran. Besides, the context-sensitive nature of the present study was not actually observed in the previous findings. This study also led to identifying different social and structural circumstances that could emphasise employee voice. Besides, the concept of voice was further highlighted in the literature. Given the integrated perspective toward the concept of voice, the present study has investigated the conceptual and empirical characteristics of the integrative model regarding employee voice. Based on the interviewees' opinions, we can define the employee voice as: "A provided opportunity for suggestions and ideas which tends to improve and develop the organisational processes, affection, tension prevention, creativity, innovation, and employee job satisfaction". This definition is the same as Wilkinson et al. (2014), Islam et al. (2019) and Van Dyne and LePine (1998). The knowledge employee voice is a constructive interaction and axial change. The goal of voice is to improve the current situation by providing suggestions and advice for changes, even if some people in an organisation disagree (Kim, Rosen, \& Lee, 2009). Based on interviews, the organisational voice is something optional, so it is not the management force-choice. There is no punishment for disobeying it.

Voice climate refers to the employees' perception of their motivation to voice their ideas and offer recommendations at work. According to the primary empirical studies' findings, the development of voice climate can lead to the employees' willingness to propose suggestions for improvement. In an organisation, we need a voice atmosphere, and the employees must interact with the manager; this is also asserted by Huang and Paterson (2017). Given that the employees would establish a sense of empowerment over their job and proactively respond to the customers' needs, developing a proactive workplace (e.g. voice climate) might improve the delivery of services to clients. Voice behaviour encourages an organisation to establish trust in employees and encourages employees to help the organisation (Kim, Choi, Borchgrevink, Knutson, \& Cha, 2018). According to the respondents, the voice space in each group is different from other groups, and some groups are just silent in this space, while others have a strongly pro-voice atmosphere. Having a suitable support space leads to presenting creative and innovative ideas in different situations, this leads to overcoming the critical situation. Additionally, they suggested that listening to employees' voice offers a win-win solution to a severe organisational problem, and mentioned how the organisation could achieve its goals using that solution.

Employee voice can lead to the involvement of employees as well as the improvement of performance, but only if there is genuine information sharing. Statistics show that if the companies grant their employees the opportunity to share ideas and declare their 
dissatisfaction, they will experience a lower staff flow rate. Accordingly, developing skills and knowledge and participation in decision-making procedures can be regarded as the influential employee voice. As a result, only employees will be able to make an influential contribution voice. Direct communication between managers and employees should be encouraged, and emphasis should be placed on the quality of the information shared and trust. In order to build trust in an organisation, the adversarial relationship between management and employees who speak up should be eliminated, and the fear feeling should be minimised (Constantin \& Baias, 2015). Finally, it should be noted that the enhancement of performance and employees' involvement are by-products of informed employee voice. Therefore, it can significantly contribute to communication by clarifying its importance and value.

According to the respondents, knowledge workers use their knowledge for making decisions. Managers must allow their employees to speak and take part in decision-making if they genuinely want to hear the employees' voice. The content of the message is effective in the decision-making process of employees, but depending on the circumstances, it cannot consistently be regarded as effective. Age and experience are among the factors affecting the occurrence of voice.

Employee voice helps to introduce some capabilities of employees (Fuller, Barnett, Hester, Relyea, \& Frey, 2007). Based on Farndale, Van Ruiten, Kelliher and Hope-Hailey (2011) findings, the opportunity to talk in an organisation increases employee commitment. The employee voice includes beliefs, concerns, or practical ideas related to the work issues, along with positive results such as innovation, improving the job process and preventing challenges. On a theoretical basis, the voice usually is a kind of optional speech, which is used for talking about opinions and influential ideas about job issues; it helps an organisation be more effective (Liang et al., 2012). The organisational voice is volunteer action, and one cannot manage it by force or set punishment because of its vacancy. For presenting the voice, the employees evaluate both the suitability of the background (is it suitable to speak or not?) and the interaction with the manager; therefore, the management interaction is the crucial indicator that encourages employees to take a risk about voice (Huang \& Paterson, 2017).

Group work is an answer to world economic competitions and permanent technological innovations (Gelfand, Erez, \& Aycan, 2007). The interactions reinforce team members' relations and obligations. The entity of interactions helps them share their ideas and opinions (Kim et al., 2018). Based on this research results, group work is a cause of constructive ideas that can improve the execution process, so we can expect that this situation increases interaction, job satisfaction and commitment. The employees expect their organisation participation and volunteer opportunity outside management hierarchy, so they freely talk about their opinions (Wang, Xu, Sun, \& Liu, 2019). When the productive speech is encouraged, the voice enables the employees to improve their perspective about the organisation.

As a consequence, we can expect a rise in voice behaviour and job satisfaction in an organisation. According to this point, that voice helps the organisation achieve goals, and managers must prepare situations and facilities for the employees' ideas to be presented. Such activities can improve the process of the voice of knowledge employees of knowledgebased companies in Iran.

Accordingly, the respondents clarified that the more exclusive the company's products are, the more people express their voice and the longer the cooperation between the supplier and the company to enhance the operating performance will encourage employees to express their voice. Employees express their voices both positively and negatively, depending on how much knowledge and expertise of the workforce is required in the environment.

Based on the point that the employee voice helps the organisation reach its goals, managers have to provide the required situations and facilities for constructive employees' 
REGE 29,2

ideas. The actions that reinforce the organisation's constructive voice include appreciating the best ideas, supporting innovation, encouraging the employees to take risks, giving responsibility based on employees' capabilities and providing accessible tools for job promotion based on available opportunities and time. These are indicators that help to reduce the unsatisfactory voice. If organisations are trying to improve their performance, they should focus on information transparency. The managers have to encourage the employees about voice on work issues and problems; they help them firmly resist other employees' pressure and scare them to not talk about their ideas. The managers must reward constructive ideas and encourage others to talk. They should remark mistakes with sincerity, generosity and dignity; they can also show it through sound, principled and respectful behaviours, making employees feel that the organisation respects their cooperation and suggestions. They should ask employees about new programmes of the organisation and use them. Regarding any challenging situations, the managers have to trust the employees' capabilities and count on their help, and lead to a friendly environment through providing a joyful organisational atmosphere of happiness, which makes people feel devoted to the organisation.

Respondents specified that some employees express their voices when influenced by their colleagues because they have found that expressing voice leads to favoured results and consequences for them. Individuals can influence vital decisions in the organisation through networking and communication and eliminate decisions that may be to their detriment.

Finally, the voice of knowledge workers in knowledge-based companies leads to consequences such as achieving competitive advantage, convergence and organisational cohesion, high productivity and performance, better interaction with customers and elimination of internal conflicts and destructive competition. In general, the research results show that managers improve workplace by preventing bullying and encouraging employees' voices to improve organisations. Previous studies on employee voice have also suggested that the supervisor-subordinate relationship is an integral part of creating an effective environment on knowledge employees' voice. Thus, supervisor-subordinate relationships play an important role in employees' work environments and affect employees' feelings of mutual commitment, leading to employees' phonetic behaviour. Ultimately, knowledge company managers should strive to meet employees' demands independently, and consider flexibility with the organisation's need to maintain control and efficiency.

\section{Suggestions}

According to the research results, it is suggested to managers and heads of knowledgebased companies in Iran that, organisational culture should be changed from the atmosphere of reinforcing silence onto the climate of voice with the components of organisational learning and knowledge sharing. Manage thinking to improve partnerships and networking to improve relationships, networking and communication with other knowledge-based companies to take advantage of their opinions in critical situations. Consider the non-monopoly of managers and heads of knowledge-based companies in decision-making and implementation. Justice and proportionality should be considered in incentives and punishments. Managers and bosses need to be clear about each other's responsibilities so that people know what they need to be held accountable for. Managers and heads of knowledge-based companies should show interest in employees' opinions so that employees feel that their growth and interests are essential to the manager. Finally, to complete and develop the research, it is suggested that other researchers address issues such as identifying (1) factors affecting the culture of employees' voices, (2) factors affecting 
the success of employees' voices, (3) barriers to employees' voices and (4) appropriate solutions to remove barriers to voices in knowledge companies. Lay the foundation in other drawers and compare the components obtained from each country.

\section{Limitations and future researchers}

Although the researchers attempted to conduct the perfect study based on their capabilities, this study might have limitations. For instance, due to the qualitative research method in the present study, the data required to perform analysis and extraction of the model have been collected through interviews with experts and managers of knowledge-based companies. Therefore, the analysis was based on data collected from various perceptions of experts and not from objective sources; therefore, data might be influenced by the personal tastes of conclusions. Anyway, it has been tried to take the necessary actions to reduce these defects as much as possible, with the help of experts' unison. The present study was conducted in knowledge-based companies located in Iran. Therefore, extending the study to other companies with different working areas in Iran may have different and insufficiently reliable results. Accordingly, the suggestions of the present study for the future are as follows:

(1) It is suggested that the model of this research be considered quantitatively by researchers.

(2) Comparative study and comparison of sample companies with other companies in the country

(3) To test the accuracy of the drawing model of the present study and the level of reliability of its findings, similar research should be done in other companies and organisations.

\section{References}

Adelstein, J. (2007). Disconnecting knowledge from the knower: The knowledge worker as Icarus. Equal Opportunities International, 26(8), 853-871.

Andrews, H., Tierney, S., \& Seers, K. (2020). Needing permission: The experience of self-care and selfcompassion in nursing: A constructivist grounded theory study. International Journal of Nursing Studies, 101, 103436.

Bang, H. (2012). What prevents senior executives from commenting upon miscommunication in top management team meetings? Qualitative Research in Organizations and Management: An International Journal, 7(2), 189-208.

Bashshur, M. R., \& Oc, B. (2015). When voice matters: A multilevel review of the impact of voice in organizations. Journal of Management, 41(5), 1530-1554.

Bouncken, R. B., Kraus, S., \& Roig-Tierno, N. (2019). Knowledge-and innovation-based business models for future growth: Digitalized business models and portfolio considerations. Review of Managerial Science, 15, 1-14.

Boxall, P., Freeman, R. B., \& Haynes, P. (2018). What workers say: Employee voice in the AngloAmerican workplace. Cornell University Press.

Burris, E. R. (2012). The risks and rewards of speaking up: Managerial responses to employee voice. Academy of Management Journal, 55(4), 851-875.

Chamberlin, M., Newton, D. W., \& Lepine, J. A. (2017). A meta-analysis of voice and its promotive and prohibitive forms: Identification of key associations, distinctions, and future research directions. Personnel Psychology, 70(1), 11-71.

\section{Study of knowledge employee voice}


REGE 29,2

Charkhkar, S., Hosseini, E., \& Sabokro, M. (2021). Reflections on individual mission: Mediating the impact of strategic talent management on entrepreneurial behavior and individual voice. Journal of Research on Management of Teaching in Marine Sciences, under publish.

Chen, C. K. (2008). Causal modelling of knowledge-based economy. Management Decision, 46(3), 501-514.

Chen, S.-J., Wang, M.-J., \& Lee, S.-H. (2018). Transformational leadership and voice behaviours: The mediating effect of employee perceived meaningful work. Personnel Review, 47(3), 694-708.

Constantin, E. C., \& Baias, C. C. (2015). Employee voice • key factor in internal communication. Procedia-Social and Behavioral Sciences, 191, 975-978.

Coule, T. (2013). Theories of knowledge and focus groups in organization and management research. Qualitative Research in Organizations and Management: An International Journal, 8(2), 148-162.

Crant, J. M., Kim, T.-Y., \& Wang, J. (2011). Dispositional antecedents of demonstration and usefulness of voice behavior. Journal of Business and Psychology, 26(3), 285-297.

Cresswell, J. W. (1998). Qualitative inquiry and research design: Choosing among five traditions (pp. 1448). SAGE Publications.

Creswell, J. W. (2002). Educational research: Planning, conducting, and evaluating quantitative. Upper Saddle River, NJ: Prentice Hall.

Denzin, N. K., \& Lincoln, Y. S. (2008). Introduction: The discipline and practice of qualitative research (pp. 1-32). Sage Publications.

Detert, J. R., \& Burris, E. R. (2007). Leadership behavior and employee voice: Is the door really open? Academy of Management Journal, 50(4), 869-884.

Epstein, M. J., \& Yuthas, K. (2017). Measuring and improving social impacts: A guide for non-profits, companies and impact investors. London and New York: Routledge.

Fakhari, H. (2021). Investigation of financial problems in the process of commercializing knowledgebased products. Journal of Science and Technology Policy, 14(1), 3-20.

Farndale, E., Van Ruiten, J., Kelliher, C., \& Hope-Hailey, V. (2011). The influence of perceived employee voice on organizational commitment: An exchange perspective. Human Resource Management, 50(1), 113-129.

Freeman, R.B., \& Medoff, J.L. (1984). What do unions do. Industrial and Labor Relations Review, 38, 244.

Fuller, J. B., Barnett, T., Hester, K., Relyea, C., \& Frey, L. (2007). An exploratory examination of voice behavior from an impression management perspective. Journal of Managerial Issues, 19(1), $134-151$.

Gao, L., Janssen, O., \& Shi, K. (2011). Leader trust and employee voice: The moderating role of empowering leader behaviours. The Leadership Quarterly, 22(4), 787-798.

Gelfand, M. J., Erez, M., \& Aycan, Z. (2007). Cross-cultural organizational behavior. Annual Review of Psychology, 58, 479-514.

Grant, A. M. (2013). Rocking the boat but keeping it steady: The role of emotion regulation in employee voice. Academy of Management Journal, 56(6), 1703-1723.

Green, F., \& Tsitsianis, N. (2005). An investigation of national trends in job satisfaction in Britain and Germany. British Journal of Industrial Relations, 43(3), 401-429.

Greene, W. (2006). Growth in services outsourcing to India propellant or drain on the US economy? DIANE Publishing.

Hirschman, A. O. (1970). Exit, voice, and loyalty: Responses to decline in firms, organizations, and states (25). Harvard University Press.

Holland, P. J., Teicher, J., \& Donaghey, J. (2019). Employee voice at work. Springer.

Holley, E. C., Wu, K., \& Avey, J. B. (2019). The impact of leader trustworthiness on employee voice and performance in China. Journal of Leadership and Organizational Studies, 26(2), 179-189. 
Hosseini, E., \& Sabokro, M. (2021). A conceptual model of organizational voice with an interpretive structural modelling approach: A study on Yazd University, Iran. Journal of Business Strategy Finance and Management, 3(2), 34-47. doi:10.12944/JBSFM.03.01-02.05.

Hosseini, E., Saeida Ardekani, S., \& Sabokro, M. (2021a). Conceptual model of the voice of the members of the scientific board of public universities of Iran with the approach of interpretive structural modelling. Journal of Research on Management of Teaching in Marine Sciences, 7(4), 16-41.

Hosseini, E., Saeida Ardekani, S., \& Sabokro, M. (2021b). Investigating the leadership integrity on the voice of the employees by mediating the empowering behaviours of the leader (a case study: Yazd travel agencies). Journal of Tourism and Development, 10(1), 241-256.

Hu, Y., Zhu, L., Li, J., Maguire, P., Zhou, M., Sun, H., \& Wang, D. (2018). Exploring the influence of ethical leadership on voice behavior: How leader-member exchange, psychological safety and psychological empowerment influence employees' willingness to speak out. Frontiers in Psychology, 9, 1718.

Huang, L., \& Paterson, T. A. (2017). Group ethical voice: Influence of ethical leadership and impact on ethical performance. Journal of Management, 43(4), 1157-1184.

Hyman, J. (2018). Employee voice and participation: Contested past, troubled present, uncertain future. Routledge.

Islam, T., Ahmed, I., \& Ali, G. (2019). Effects of ethical leadership on bullying and voice behavior among nurses: Mediating role of organizational identification, poor working condition and workload. Leadership in Health Services, 32(1), 2-17.

Kamarudin, M. F., Starr, K., Abdullah, A. N., \& Husain, K. (2014). Communicating change in organizational restructuring: A grounded theory case study. In Paper presented at the $i$-COME 2014: Communication, Empowerment and Governance: The 21st Century Enigma: Proceedings of the International Conference on Communication and Media 2014 (i-COME).

Kantur, D. (2016). Strategic entrepreneurship: Mediating the entrepreneurial orientation-performance link. Management Decision, 54(1), 24-43.

Kaufman, B. E. (2015). Theorising determinants of employee voice: An integrative model across disciplines and levels of analysis. Human Resource Management Journal, 25(1), 19-40.

Khanmoradi, S., Sajjadi, S. N., \& Zardoshtian, S. (2020). Establishing a knowledge-based company in the field of sports science: A model mixed approach. Applied Research in Sport Management, 8(3), 113-128.

Kim, T. Y., Rosen, B., \& Lee, D. R. (2009). South Korean managerial reactions to voicing discontent: The effects of employee attitude and employee communication styles. Journal of Organizational Behavior: The International Journal of Industrial, Occupational and Organizational Psychology and Behavior, 30(7), 1001-1018.

Kim, M., Choi, L., Borchgrevink, C. P., Knutson, B., \& Cha, J. (2018). Effects of Gen Y hotel employee's voice and team-member exchange on satisfaction and affective commitment between the US and China. International Journal of Contemporary Hospitality Management, 30(5), 2230-2248.

Kok, S. B., Sarikaya, M., \& Coban, H. (2016). Organizational voice behavior and its investigation in terms of organizational variables. European Scientific Journal, 12(35), 16-33.

Kryscynski, D., Coff, R., \& Campbell, B. (2021). Charting a path between firm-specific incentives and human capital-based competitive advantage. Strategic Management Journal, 42(2), 386-412.

Liang, J., Farh, C. I., \& Farh, J.-L. (2012). Psychological antecedents of promotive and prohibitive voice: A two-wave examination. Academy of Management Journal, 55(1), 71-92.

Liu, D.-R., \& Wu, I.-C. (2008). Collaborative relevance assessment for task-based knowledge support. Decision Support Systems, 44(2), 524-543.

Madhoshi, M., \& Kia Kojouri, K. (2018). Identifying barriers to open innovation in universities. Journal of Research on Management of Teaching in Marine Sciences, 4(4), 1-15. 
REGE 29,2

Massey, A. P., Montoya-Weiss, M. M., \& O'Driscoll, T. M. (2005). Human performance technology and knowledge management: A case study. Performance Improvement Quarterly, 18(2), 37-55.

Maynes, T. D., \& Podsakoff, P. M. (2014). Speaking more broadly: An examination of the nature, antecedents, and consequences of an expanded set of employee voice behaviours. Journal of Applied Psychology, 99(1), 87.

Morrison, E. W., Wheeler-Smith, S. L., \& Kamdar, D. (2011). Speaking up in groups: A cross-level study of group voice climate and voice. Journal of Applied Psychology, 96(1), 183.

Mowbray, P. K., Wilkinson, A., \& Tse, H. H. (2015). An integrative review of employee voice: Identifying a common conceptualization and research agenda. International Journal of Management Reviews, 17(3), 382-400.

Mowbray, P. K., Wilkinson, A., \& Tse, H. H. (2019). Evolution, separation and convergence of employee voice concept. In Employee voice at work (pp. 3-21). Springer.

NawzadSabir, M., Othman, B., Al-Kake, F., \& Rashid, W. (2019). The influence of entrepreneurship characteristics on attitude towards knowledge commercialization. International Journal of Psychosocial Rehabilitation, 23(2), 566-582.

Nicolopoulou, K., Karatas-Ozkan, M., \& Tatli, A. (2007). Practising knowledge workers: Perspectives of an artist and economist. Equal Opportunities International, 26(8), 872-878.

Norman, S. M., Avey, J., Larson, M., \& Hughes, L. (2019). The development of trust in virtual leaderfollower relationships. Qualitative Research in Organizations and Management: An International Journal, 15(3), 279-295.

Ötken, A. B., \& Cenkci, T. (2012). The impact of paternalistic leadership on ethical climate: The moderating role of trust in leader. Journal of Business Ethics, 108(4), 525-536.

Palalic, R. (2017). The phenomenon of entrepreneurial leadership in gazelles and mice: A qualitative study from Bosnia and Herzegovina. World Review of Entrepreneurship, Management and Sustainable Development, 13(2-3), 211-236.

Pohler, D. M., \& Luchak, A. A. (2014). The missing employee in employee voice research. In Handbook of research on employee voice: Elgar original reference (p. 188).

Pyman, A., Cooper, B., Teicher, J., \& Holland, P. (2006). A comparison of the effectiveness of employee voice arrangements in Australia. Industrial Relations Journal, 37(5), 543-559.

Reed, R., \& DeFillippi, R. J. (1990). Causal ambiguity, barriers to imitation, and sustainable competitive advantage. Academy of Management Review, 15(1), 88-102.

Sabokro, M., Kayedian, A., \& Hosseini, E. (2021). Identifying retention risks in faculty member. Journal of Research on Management of Teaching in Marine Sciences, 8(1), 1-17.

Salamzadeh, A., \& Kawamorita Kesim, H. (2017). The enterprising communities and startup ecosystem in Iran. Journal of Enterprising Communities: People and Places in the Global Economy, 11(4), 456-479.

Salamzadeh, A., \& Tajpour, M. (2021). Identification of the challenges of media startup creation in Iran. Journal of Entrepreneurship Development, 13(4), 561-580.

Salamzadeh, A., Tajpour, M., \& Hosseini, E. (2019). Corporate entrepreneurship in university of Tehran: Does human resources management matter? International Journal of Knowledge-Based Development, 10(3), 276-292.

Salamzadeh, A., Tajpour, M., Hosseini, E., \& Salembrahmi, M. (2021). Human capital and the performance of Iranian digital startups: The moderating role of knowledge sharing behavior. International Journal of Public Sector Performance Management, (In prepration).

Strauss, A., \& Corbin, J. (1990). Basics of qualitative research. Sage Publications.

Strauss, A. L., \& Corbin, J. (2008). Pesquisa qualitativa: Técnicas e procedimentos para o desenvolvimento de teoria fundamentada. Artmed.

Strauss, G. (2006). Worker participation - Some under-considered issues. Industrial Relations: A Journal of Economy and Society, 45(4), 778-803. 
Stromquist, N. P., Gil-Antón, M., Colatrella, C., Mabokela, R. O., Smolentseva, A., \& Balbachevsky, E. (2007). The contemporary professoriate: Towards a diversified or segmented profession? Higher Education Quarterly, 61(2), 114-135.

Sveiby, K. E. (1997). The new organizational wealth: Managing and measuring knowledge-based assets. Berrett-Koehler Publishers.

Tajpour, M. (2021). Towards the entrepreneurial university. Journal of Organizational Culture, Communications and Conflict, 25(3), 4-5.

Tajpour, M., \& Hosseini, E. (2021a). Entrepreneurial intention and the performance of digital startups: The mediating role of social media. Journal of Content, Community and Communication, 13, 2-15.

Tajpour, M., \& Hosseini, E. (2021b). Towards a creative-oriented university. Journal of Business Strategy Finance and Management, 2(1,2).

Tajpour, M., Hosseini, E., \& Alizadeh, R. (2021). Entrepreneurship opportunities: The effect of social entrepreneurship on the presence of Afghan immigrant youth in Iranian universities. Migration Social Entrepreneurship and Social Inclusion, 1, 261-284.

Tajpour, M., Salamzadeh, A., \& Hosseini, E. (2019). Social media and entrepreneurship in creative industries. In Proceedings of the 2nd International Conference of Research in Innovation and Technology, Tehran.

Tangirala, S., Kamdar, D., Venkataramani, V., \& Parke, M. R. (2013). Doing right versus getting ahead: The effects of duty and achievement orientations on employees' voice. Journal of Applied Psychology, 98(6), 1040.

Townsend, K. (2014). The role of line managers in employee voice systems. Handbook of Research on Employee Voice, (Supp. 10), 155-169.

Van Dyne, L., \& LePine, J. A. (1998). Helping and voice extra-role behaviours: Evidence of construct and predictive validity. Academy of Management Journal, 41(1), 108-119.

Wang, C. L., \& Ahmed, P. K. (2003). Structure and structural dimensions for knowledge-based organizations. Measuring Business Excellence, 7(1), 51-62.

Wang, Z., Xu, S., Sun, Y., \& Liu, Y. (2019). Transformational leadership and employee voice: An affective perspective. Frontiers of Business Research in China, 13(1), 2.

Wei, X. G., Kang, K., Zhang, J., \& Zhang, Z. Y. (2016). Study on the network power and the path of network power on the competitive advantage in global value chain - Exploratory research based on grounded theory. Soft Science, 4, 15-45.

Welbourne, T. M. (2011). 50 Years of voice in HRM. Human Resource Management, 50(1), 1-2.

Wilkinson, A., Dundon, T., Donaghey, J., \& Freeman, R. (2014). Employee voice: Charting new terrain. In The handbook of research on employee voice: Participation and involvement in the workplace (pp. 1-16).

Zahra, S. A. (2007). Contextualizing theory building in entrepreneurship research. Journal of Business Venturing, 22(3), 443-452.

\section{About the authors}

Elahe Hosseini is a Ph.D. in Organizational Behaviour and Human Resource Management, Yazd University. Her research interest is about organisation behaviour, human resource management and social and entrepreneurship activities to develop entrepreneurship in developing countries. Also, she has several publications in international journals and participated in several conferences in some countries. She serves as an editor, a member of the editorial board in a series of distinguished journals such as the Iranian Journal of Management Studies and International Journal of Management and Enterprise Development. The title of her doctoral thesis is about employee voice of knowledge-based companies in Iran.

Saeid Saeida Ardekani is a Full Professor in Faculty of Economics, Management and Accounting, Yazd University. His research area is about management and marketing. Also, he has several publications in international journals and participated in several conferences in some countries. 
REGE

29,2

138

Mehdi Sabokro is an Associate professor in Faculty of Economics, Management and Accounting, Yazd University. His research area is about organisation behaviour and human resource management. Also, he has several publications in international journals and participated in several conferences in some countries. Mehdi Sabokro is the corresponding author and can be contacted at: msabokro@yazd. ac.ir

Aidin Salamzadeh is assistant professor in University of Tehran. He has several publications in journals such as Journal of Economic Psychology, Journal of Enterprising Communities, Journal of Enterprising Culture, and International Journal of Entrepreneurship and Small Business. His main areas of interest are contextual entrepreneurship, start-ups, new venture creation, media entrepreneurship, and social entrepreneurship. He serves as an editor, a member of the editorial board in a series of distinguished journals such as The Bottom Line (Emerald). He is also a member of the European SPES Forum (Belgium), the Asian Academy of Management (Malaysia), Institute of Economic Sciences (Serbia), and Ondokuz Mayis University (Turkey).

Associate editor: Rodrigo Morais-da-Silva

For instructions on how to order reprints of this article, please visit our website: www.emeraldgrouppublishing.com/licensing/reprints.htm Or contact us for further details: permissions@emeraldinsight.com 